Journal of Tropical Ecology

www.cambridge.org/tro

\section{Research Article}

Cite this article: Folt B and Guyer C (2021) Habitat-dependent effects of predatory spiders on prey frogs in a Neotropical wet forest. Journal of Tropical Ecology 37, 214-221. https:// doi.org/10.1017/S0266467421000274

Received: 26 May 2020

Revised: 11 April 2021

Accepted: 19 June 2021

First published online: 16 August 2021

\section{Keywords:}

co-occurrence patterns; Craugastor bransfordii; Ctenidae; habitat; La Selva; occupancy analysis; Oophaga pumilio; population regulation; predator-prey dynamics

\section{Author for correspondence:}

Brian Folt, Email: brian.folt@gmail.com

\title{
Habitat-dependent effects of predatory spiders on prey frogs in a Neotropical wet forest
}

\section{Brian Folt (1) and Craig Guyer}

Department of Biological Sciences and Auburn University Museum of Natural History, 331 Funchess Hall, Auburn, Alabama 36849, USA

\begin{abstract}
In seasonal wet Neotropical forests, many studies have suggested that species-rich terrestrial frog assemblages are regulated bottom-up by the abundance of leaf litter. However, terrestrial frogs are prey to a diverse community of predators, and no studies have tested for top-down effects of predators on this or other anuran assemblages. Here, we used an extensive field dataset to model the relative contribution of food resources, microhabitat resources and predators towards the occupancy and detection of two frog species (Craugastor bransfordii and Oophaga pumilio) at La Selva, Costa Rica. Frog occupancy was most strongly influenced by predatory spiders and secondarily influenced by the abundance of leaf litter. Predators exerted stronger effects on frogs than food resources, and frogs avoided predators more as leaf litter decreased. Detection probability was elevated when predators were present. We found support for bottom-up effects of leaf litter on the terrestrial frog assemblage, but top-down effects by predators exerted stronger effects on frog occupancy and detection. Because predator avoidance varied along a resource gradient, predator and resource effects appear to be dependent, supporting interactions between top-down and bottom-up mechanisms. Climate-driven decreases in leaf litter may drive decreased availability of frog refugia and increased interactions between frogs and predators.
\end{abstract}

(c) The Author(s) 2021. Published by Cambridge University Press. This is an Open Access article, distributed under the terms of the Creative Commons Attribution licence (http:// creativecommons.org/licenses/by/4.0/), which permits unrestricted re-use, distribution and reproduction, provided the original article is properly cited.

\section{CAMBRIDGE} UNIVERSITY PRESS

\section{Introduction}

A fundamental goal of ecology is to understand mechanisms that regulate the dynamics of populations and communities. In wet Neotropical forest ecosystems, a diverse assemblage of small terrestrial frogs occupies the leaf-litter layer on the forest floor, and a large body of literature has suggested that the 'leaf-litter frog assemblage' is regulated bottom-up (sensu Hunter \& Price, 1992) by the abundance of leaf litter. Species in the leaf-litter assemblage use litter to obtain abundant arthropod food resources (Toft 1980, Lieberman 1986, Whitfield \& Donnelly 2006), to select habitat to limit desiccation across life stages (including during oviposition; Seebacher and Alford 2002; Schlaepfer 2003; Socci et al. 2005) and to take refuge from a diverse array of predators (Talbot 1979, Greene 1988, Cooper et al. 2008a, 2008b). Several studies have documented a positive relationship between standing leaf litter and abundance of terrestrial frogs and anoles in mainland ecosystems (Scott 1976, Lieberman 1986, Guyer 1988, Fauth et al. 1989, Heinen 1992, Whitfield et al. 2007), and Whitfield et al. (2014) provided the first experimental demonstration of standing leaf litter as a density-limiting factor. The leaf-litter frog assemblage declined $75 \%$ in abundance over a 35-year period at La Selva Biological Station in Costa Rica, and a climate-driven decline in standing leaf-litter mass was identified as the most likely source of this enigmatic amphibian decline (Whitfield et al., 2007, 2014). Thus, a common thread among studies is the identification of leaf litter as a fundamental resource regulating the abundance of the leaf-litter frog assemblage, in ways consistent with bottom-up regulation (sensu Hunter and Price 1992).

While a large literature has studied resource limitation and bottom-up regulation of terrestrial frogs in the Neotropics (e.g., Whitfield et al. 2014, 2016), much less consideration has been given how predators can exert top-down effects on frogs in the leaf-litter assemblage. The lack of information on top-down effects is surprising because the leaf-litter frog assemblage is prey to a diverse assemblage of both vertebrate and invertebrate predators (Greene 1988). For example, La Selva Biological Station in Costa Rica (hereafter, La Selva) is home to an extremely species-rich community of vertebrate predators, but one of the most frequent predators of small frogs may actually be invertebrates. In particular, large Wandering Spiders (Ctenidae) are a common generalist predator occupying terrestrial environments in lowland Neotropical wet forests of Costa Rica. Ctenids attack and consume terrestrial and arboreal frogs in the families Centrolenidae, Craugastoridae and Hylidae (Hayes 1983, Szelistowski 1985, Donnelly \& Guyer 1994, Lapinski \& Tschapka 2013, Folt \& Lapinski 2017) but frequently reject the poisonous frog Oophaga pumilio (Szelistowski 
Figure 1. Two species of abundant terrestrial frogs and a predatory spider (Ctenidae) from lowland Caribbean forests of Costa Rica: (A) Craugastor bransfordii, (B) Oophaga pumilio and $(C)$ Cupiennius sp. consuming a rain frog (Pristimantis ridens). See Folt and Lapinski (2017) for other examples of ctenid spiders consuming various frog species from the Caribbean lowlands of Costa Rica. Photographs by J. Folt (A, B) and W. Lapinski (C).

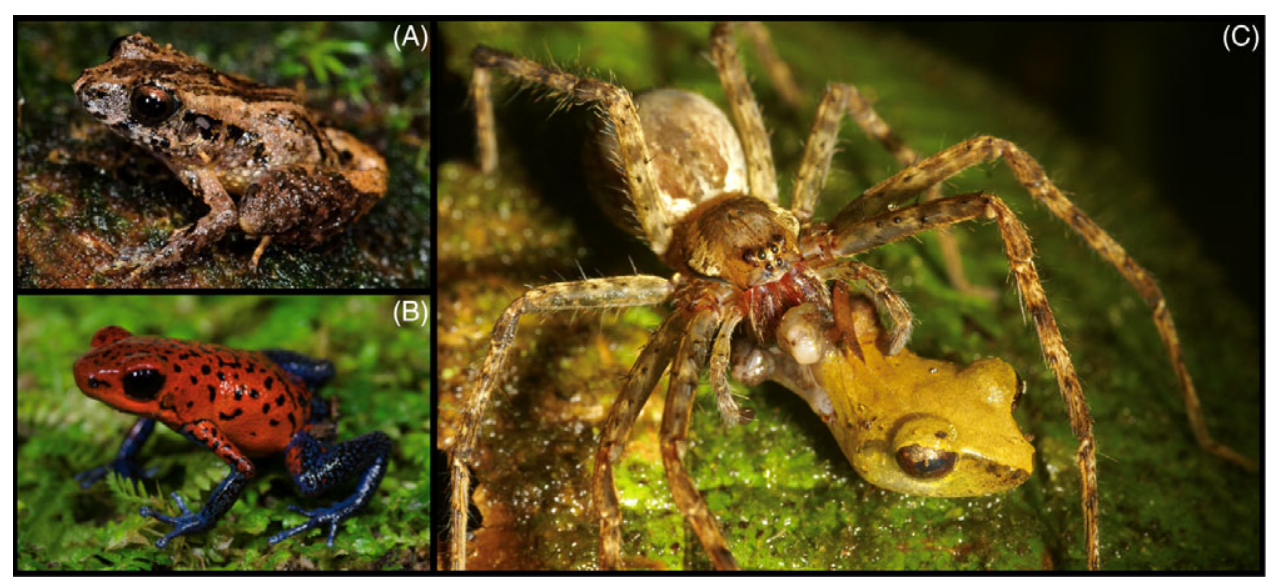

1985, Murray et al. 2016, Folt \& Lapinski 2017). Ctenids are also capable of consuming small reptiles, being the most commonly observed source of predation during detailed studies of the anole Norops humilis (Guyer 1988), and ctenids are dominant predators of metamorphic hylid frogs emerging from ephemeral swamps (Donnelly \& Guyer 1994). The latter study observed a strong pulse in metamorphosis of frogs and hypothesised that this synchronous emergence may have evolved as a mechanism to satiate terrestrial spider predators (Donnelly \& Guyer 1994, Guyer \& Donnelly 2005). Recent studies from Central and South America have also found that ctenids are opportunistic predators of small vertebrates (Menin et al. 2005, Maffei et al. 2010, Nyffeler \& Altig 2020, Reyes-Olivares et al. 2020, Meneses et al. 2021), and the accumulating literature suggests that spiders may play an important role as vertebrate predators across Neotropical wet forests (Hayes 1983, Guyer 1988, Donnelly \& Guyer 1994, Menin et al. 2005). However, no study has examined the extent to which ctenid spiders influence terrestrial frogs or other small vertebrates in a top-down, predator-prey context.

In recent decades, amphibian populations have declined significantly across the world, and declines have been linked to habitat change, invasive species, climate change, pollution, contaminants and emerging infectious diseases (Stuart et al. 2004, Mendelson et al. 2006, Whitfield et al. 2016, Scheele et al. 2020). While the current paradigm for the leaf-litter frog assemblage suggests that it is bottom-up regulated by leaf litter, understanding top-down effects may be particularly important because predation pressure may interact with resources in ways important for understanding the amphibian decline crisis in Central America and elsewhere. Because leaf litter has declined strongly at sites like La Selva (Whitfield et al., 2007) and the terrestrial frog assemblage uses leaf litter to hide from predators (Talbot 1979, Greene 1988, Cooper et al. 2008a, 2008b), decreased litter availability may have caused predator-prey dynamics to shift such that frogs are now experiencing increased interactions with predators. Thus, understanding interactions between top-down and bottom-up regulatory factors might also provide insights into novel mechanisms for population regulation of declining terrestrial frogs in the Neotropics.

To this end, we sought to better understand top-down effects on the ecology of leaf-litter frogs in lowland wet Neotropical forests where ctenid spiders are frequent predators on terrestrial anurans. We used multi-species occupancy models to quantify patterns of site occupancy and detection for two small terrestrial frog species (Craugastor bransfordii and Oophaga pumilio) at La Selva Biological Station, and we modelled how frog occupancy and detection probability were influenced top-down by predatory spiders and bottom-up by resources (arthropod prey and leaf-litter microhabitat). Given the hypothesis that ctenid spiders are important predators of terrestrial frogs in the Neotropics (Menin et al. 2005, Maffei et al. 2010, Folt \& Lapinski 2017, von May et al. 2019, Nyffeler \& Altig 2020, Reyes-Olivares et al. 2020, Meneses et al. 2021), we predicted that small terrestrial frogs would experience elevated occupancy in areas where predatory spiders are absent relative to where predators are present. To understand potential interactions between top-down and bottom-up factors, we also evaluated how top-down effects interacted with resources, by modelling how predator-prey interactions varied along a leaf-litter resource gradient.

\section{Materials and methods}

\section{Study site and taxa}

La Selva Biological Station (hereafter, La Selva) is a private reserve owned by the Organization for Tropical Studies (OTS) in the Caribbean lowlands of northeastern Costa Rica $\left(10.42^{\circ} \mathrm{N}\right.$, $84.02^{\circ} \mathrm{W}$; WGS 84 ). The site is characterised by an average temperature of $25.8^{\circ} \mathrm{C}$, receives ca. $4 \mathrm{~m}$ of precipitation/year and is classified as a Tropical Wet Forest in the Holdridge life zone system (McDade et al. 1994).

We studied two common terrestrial frogs and an assemblage of ctenid spiders from La Selva as the focal taxa (Figure 1). Craugastor bransfordii is an abundant frog species (Craugastoridae) that is highly variable in colouration; variation has been categorised into at least four distinct morphs defined by colour and dorsal ridging patterns, which are thought to decrease predation in the terrestrial leaf-litter environment (Savage \& Emerson 1970, Cooper et al. 2008b). Oophaga pumilio is an aposematic poison frog (Dendrobatidae) that also occupies terrestrial habitats; the species primarily eats ants and mites (Donnelly 1991), a diet which provides alkaloid compounds that are sequestered into poison glands in the frog's skin and confers an antipredatory defence (Saporito et al. 2004, 2007a, Stynoski et al. 2014b). Across its geographic distribution, O. pumilio is brightly coloured, which serves as an aposematic signal to reduce predation (Saporito et al. 2007b). Ctenid spiders are common generalist predators occupying terrestrial 
environments in lowland Caribbean forests of Costa Rica. Three species in the genus Ctenus are conspicuous residents at $\mathrm{La}$ Selva (Ctenus curvipes, Ctenus sinuatipes and an undescribed Ctenus species; W. Lapinski, pers. comm.) which consume small vertebrates (Szelistowski 1985, Guyer 1988, Lapinski \& Tschapka 2013). In primary forest habitats like La Selva, these ctenid species are visual ambush predators that emerge from hidden sites in soil and leaf litter (Lapinski \& Tschapka 2013) to attack prey (e.g., Folt and Lapinski 2017). Identification of Ctenus species is difficult in the field because the species are morphologically similar and also exhibit high intraspecific variation. Thus, we considered all ctenids as a single group in our analyses.

Because the focal frogs are relatively mobile compared to sit-andwait predatory ctenids (B. Folt, pers. obs.), prey species should respond to predation threat through shifts in space, habitat use or behaviour (i.e., the prey response dominates; Sih 1984). Therefore, if spider predation exerts a strong ecological pressure on frogs, we predicted that, relative to sites where spiders were absent, the presence of spiders would decrease patterns of occupancy and detection of frogs (Andrews 1979, Losos 2009). However, because $O$. pumilio is chemically defended and ctenids have rejected O. pumilio during feeding trials (Szelistowski 1985, Murray et al. 2016), we also predicted that $O$. pumilio would occupy sites independent of spiders as a result of a lack of perceived predation threat.

\section{Data collection}

We established replicate gridded plots around individual canopy trees $(\mathrm{N}=14)$ in primary forest habitat; plot grids consisted of 21 cells that were each $3 \mathrm{~m} \times 3 \mathrm{~m}$ in area $\left(189 \mathrm{~m}^{2}\right.$ total $)$ and were marked using PVC tubing (Figure S1; Folt 2017). We used plots of this area because comparable-sized plots were successfully used in other studies of amphibian and reptile population ecology at La Selva (Guyer 1988, Donnelly 1989, Whitfield et al. 2014).

All 21 plot cells were sampled for frogs and spiders in February, May, June, August, September, October and November 2014. We surveyed animals using diurnal visual encounter searches of the forest floor and other substrates up to $2 \mathrm{~m}$ above ground. We walked methodically through plots to search all cells and carefully prodded through the litter and other structures with a $1.2-\mathrm{m}$ pole. Each plot cell was surveyed repeatedly $(\mathrm{N}=3)$ during each month. We conducted the first survey on a randomly selected day and generally repeated surveys on the two consecutive days. Our sampling method focused on counting frogs, lizards and spiders present on the forest floor, or immediately adjacent vertical structures up to $1 \mathrm{~m}$ above the ground. However, the vast majority of samples were taken from the forest floor.

We quantified abundance of leaf litter and terrestrial arthropods in four randomly selected plot cells in each month. For leaf-litter and arthropod samples, we randomly selected a corner of each plot cell and used a $0.30 \mathrm{~m} \times 0.30 \mathrm{~m}$ PVC frame to delimit samples of litter, cut the perimeter of the litter with a utility blade and collected the sample into a plastic bag. Before cutting out the litter, we measured leaf-litter depth $(\mathrm{cm})$ and the number of leaves in the litter column in each corner of the PVC frame. We brought the samples into the laboratory and dried them in Berlese funnels beneath heated incandescent bulbs for 24-48 hours or until no moisture appeared to remain in the samples; during the drying process, arthropods were driven downward from within the drying litter and collected in vials containing 95\% ethanol. We measured dried leaf-litter mass (g) and used a microscope to sort arthropods into taxonomic groups that are important components of the diets of the study species (Whitfield \& Donnelly 2006, Folt 2017). Because leaf-litter and arthropod samples were collected from the corner of plot cells (Figure S1), we used the frog and spider survey data from each plot cell with resources covariates and any plot cells immediately adjacent to a resource covariate sample to model predator-prey occupancy. Our additional estimates of leaf-litter abundance (depth and number of leaves) were characterised by strong positive relationships with dried leaf-litter mass (B. Folt, unpubl. results); however, we chose to use estimates of dried leaf-litter mass as our primary assay of leaf-litter abundance because this estimate controls for moisture, which is highly variable in space and time due to rainfall in tropical wet forests like La Selva, and was paired with our estimate of arthropod food resources in the samples.

\section{Statistical analysis}

When species are detected imperfectly (detection probability $<1.0$ ), analyses of co-occurrence patterns can be misleading and result in erroneous inferences (MacKenzie et al. 2006). We took advantage of recent advances in quantitative ecology that have developed statistical methods to account for imperfect detection of individuals while estimating species occupancy or abundance at sites (occupancy modelling and derivations; MacKenzie et al. 2006). In particular, such occupancy models have been expanded to include parameterisations that investigate relationships among co-occurring and potentially interacting species, such as predator-prey relationships (MacKenzie et al. 2004); these multi-species occupancy models are flexible and can include covariates, to evaluate support for competing hypotheses, such as resources, in addition to interspecific interactions (Richmond et al. 2010). Thus, we modelled how the spatial and behavioural ecology of frogs was influenced by predatory spiders and resources (leaf litter and arthropod food resources) using the $\Psi^{\mathrm{Ba}}$ parameterisation of the multi-species, single-season occupancy model (MacKenzie et al. 2004, Richmond et al. 2010). The $\Psi^{\mathrm{Ba}}$ parameterisation estimates the probability of occupancy of a dominant species (A) and a subordinate species (B). We assumed that spiders were dominant over frog species because we hypothesized that prey frogs would avoid predation risk and respond predictably to the presence of predatory spiders. Using these models, we estimated the probability of occupancy of the dominant predatory organisms $\left(\Psi^{\mathrm{A}}\right)$ and the occupancy of each subordinate taxon when dominant predators were present $\left(\Psi^{\mathrm{BA}}\right)$ and absent $\left(\Psi^{\mathrm{Ba}}\right)$.

We evaluated co-occurrence patterns between ctenids and each focal frog species separately. Preliminary analyses indicated that spiders and frogs consistently differed in patterns of occupancy and detection for the two predator-prey pairs (ctenids + C. bransfordii and ctenids $+O$. pumilio). Thus, we used a model-building process that began with creating an initial model describing variance in occupancy and detection differing between dominant and subordinant species and then built six models that included all combinations of $\Psi$ parameters (Table 1) describing hypotheses of how predatory spiders influence occupancy and/or detection of prey species (Table 2). Using this model-building process, we evaluated whether occupancy of the subordinate species was affected by the presence of the dominant species $\left(\Psi^{\mathrm{BA}} \neq \Psi^{\mathrm{Ba}}\right)$ and whether detection probability of the subordinate species was influenced by detection $\left(r^{\mathrm{BA}}\right)$ and/or occupancy $\left(r^{\mathrm{Ba}}\right)$ of the dominant species (Table 2). Our model-building process generated a balanced set of six models with even representation of predator effects $\left(\Psi^{\mathrm{BA}} \neq \Psi^{\mathrm{Ba}}, r^{\mathrm{BA}}\right.$ and $\left.r^{\mathrm{Ba}}\right)$ either present or absent in models. 
Table 1. Description of model parameters used to evaluate hypotheses describing two-species co-occurrence patterns, following Richmond et al. (2010). Species A are predators and are assumed to be dominant over the prey species $B$.

\begin{tabular}{|c|c|}
\hline Parameter & Description \\
\hline$\Psi^{A}$ & Occupancy of the dominant species A \\
\hline$\Psi^{\mathrm{BA}}$ & Occupancy of species $B$, given species $A$ is present \\
\hline$\Psi^{\mathrm{Ba}}$ & Occupancy of species $B$, given species $A$ is absent \\
\hline$p^{A}$ & $\begin{array}{l}\text { Detection probability of species A, given species B is } \\
\text { absent }\end{array}$ \\
\hline$p^{\mathrm{B}}$ & $\begin{array}{l}\text { Detection probability of species } B \text {, given species } A \text { is } \\
\text { absent }\end{array}$ \\
\hline$r^{\mathrm{BA}}$ & $\begin{array}{l}\text { Detection probability of species } B \text {, given both species } \\
\text { are present and species } A \text { is detected }\end{array}$ \\
\hline$r^{\mathrm{Ba}}$ & $\begin{array}{l}\text { Detection probability of species } B \text {, given both species } \\
\text { are present and species } A \text { is not detected }\end{array}$ \\
\hline$\Psi^{\mathrm{LL}} p^{\mathrm{LL}}$ & $\begin{array}{l}\text { Effect of leaf litter (LL) on occupancy }(\Psi) \text { or detection } \\
(p) \text { of both species }\end{array}$ \\
\hline $\begin{array}{l}\Psi^{\text {Arthropods }} \\
p^{\text {Arthropods }}\end{array}$ & $\begin{array}{l}\text { Effect of arthropod food resources on occupancy or } \\
\text { detection of both species }\end{array}$ \\
\hline
\end{tabular}

Table 2. Six models describing hypotheses for co-occurrence patterns between predatory spiders and prey frogs in forest plots at La Selva, Costa Rica. Species A is assumed to be dominant over species B. All models include terms describing species $A$ and $B$ differing in probability of occupancy and detection.

\begin{tabular}{ll}
\hline Model & Hypotheses \\
\hline$\Psi^{\mathrm{BA}}, \Psi^{\mathrm{Ba}}$ & Occupancy of species A affects the occupancy of species B \\
\hline$\Psi^{\mathrm{BA}}, \Psi^{\mathrm{Ba}}$, & $\begin{array}{l}\text { Occupancy and detection of species A affects the } \\
\text { occupancy and detection of species B }\end{array}$ \\
\hline$r^{\mathrm{BA}}$ & $\begin{array}{l}\text { Occupancy of species A affects the occupancy and detec- } \\
\Psi^{\mathrm{BA}}, \Psi^{\mathrm{Ba}}, \\
r^{\mathrm{BA}}, r^{\mathrm{Ba}}\end{array}$ \\
\hline$\Psi^{\mathrm{BA}}$ & $\begin{array}{l}\text { No interactions between species affecting occupancy or } \\
\text { detection; null model }\end{array}$ \\
\hline$\Psi^{\mathrm{BA}}, r^{\mathrm{BA}}$ & $\begin{array}{l}\text { No interactions between species affecting occupancy; } \\
\text { occupancy and detection of species A influences the } \\
\text { detection of species B }\end{array}$ \\
\hline$\Psi^{\mathrm{BA}}, r^{\mathrm{BA}}, r^{\mathrm{Ba}}$ & $\begin{array}{l}\text { No interactions between species affecting occupancy; } \\
\text { occupancy of species A affects the detection of species } \\
\text { B, whether or not species A is detected }\end{array}$ \\
\hline
\end{tabular}

To evaluate the relative roles of resources and predators contributing to frog ecology, we built 54 additional models to evaluate how frog occupancy and detection are explained by predators and resources. We expanded the initial six models (Table 2) to include covariate effects (litter mass and arthropod abundance) on occupancy, detection, and both occupancy and detection, in the presence and absence of predator effects. Because rainfall is strongly seasonal at La Selva and seasonal rainfall is thought to influence patterns of leaf-litter deposition, arthropod abundance, and abundance of terrestrial frogs and lizards (Frankie et al. 1974, Lieberman \& Dock 1982, Guyer 1988), we also built models evaluating how seasonality influenced patterns of occupancy and detection. The second model-building process generated 54 additional models with different combinations of predator, food resources, seasonal effects and null models in a completely balanced design $(\mathrm{N}=60$ models; Supplementary Table 1). We modelled the arthropod covariate differently for each species depending on its diet (Lieberman 1986, Whitfield \& Donnelly 2006): the sum of Acari, Araneae, Coleoptera and Isopoda abundance for C. bransfordii, and Acari and Formicidae for O. pumilio. We transformed all covariates by $\log (\mathrm{x}+1)$ to improve model convergence. We classified seasonality by categorising months as 'dry' (February-May) and 'wet' (June-November) based on historical mean monthly precipitation values (Guyer 1988) and by heuristically assessing rainfall data from La Selva during 2014 (B. Folt, pers. obs.).

We evaluated how well each model fit the data using Akaike's Information Criterion corrected for small sample size $\left(\mathrm{AIC}_{c}\right.$; Hurvich and Tsai 1989) and calculated the probability a given model within a set is the best approximating model (model weight; $\left.w_{m}\right)$. We then used model weights to calculate model-averaged coefficients ( \pm unconditional SE) and model-averaged parameter weights $\left(w_{p}\right)$ across all models with $w_{m}>0.025$. We considered parameters as explaining significant variation when they occurred in a model in the top model set $\left(\Delta \mathrm{AIC}_{\mathrm{c}}<2.00\right)$, unconditional SE estimates did not overlap, and $w_{p}>0.70$ (Burnham \& Anderson 2010).

Our analyses indicated significant predator-prey interactions in the top-model set by supporting the $\Psi^{\mathrm{Ba}}$ parameter in the top model; we therefore calculated a species interaction factor (SIF). The SIF describes if the predator-prey pairs co-occur more frequently (SIF $>1$ ) or less frequently $($ SIF $<1)$ than expected if species did not interact and occupancy probabilities were independent of each other $\left(\mathrm{SIF}^{\sim} 1\right)$. We calculated the SIF using model-averaged parameter estimates and by following the SIF equation described by Richmond et al. (2010):

$$
\mathrm{SIF}=\frac{\Psi^{\mathrm{A}} * \Psi^{\mathrm{BA}}}{\Psi^{\mathrm{A}}\left(\Psi^{\mathrm{A}} * \Psi^{\mathrm{BA}}+\left(1-\Psi^{\mathrm{A}}\right) * \Psi^{\mathrm{Ba}}\right)}
$$

We performed all analyses in the statistical Program R (R; R Core Team 2018). We built single-season, two-species occupancy models using the function occmod() in the package 'RPresence' (MacKenzie \& Hines 2016). In our analysis, we treated plot cells with covariates within each month as 'sites' (sensu MacKenzie et al. 2006), such that individual plot cells sampled repeatedly among months were considered independent replicate samples. Our data, model code, and software packages are available on GitHub (https://github.com/brianfolt/predator-prey-models.git).

\section{Results}

During February-November 2014, we made 946 detections of C. bransfordii, 343 detections of $O$. pumilio and 271 detections of ctenid spiders during 3144 surveys of 1048 plot cells. Top-model sets of co-occurrence models for each predator-prey pair contained parameters describing interactions between predators and prey $\left(\Psi^{\mathrm{Ba}}, r^{\mathrm{BA}}\right.$ and $\left.r^{\mathrm{Ba}}\right)$ and effects of leaf litter on occupancy and detection ( $\Psi^{\mathrm{LL}}$ and $p^{\mathrm{LL}}$; Table 3 ).

The top model for both frog species included the terms $\Psi^{\mathrm{Ba}}$, $\Psi^{\mathrm{LL}}, r^{\mathrm{BA}}$ and $r^{\mathrm{Ba}}$ (Table 3), a model which indicated effects of predators $\left(\Psi^{\mathrm{Ba}}\right)$ and leaf litter $\left(\Psi^{\mathrm{LL}}\right)$ on frog occupancy and a predator effect on frog detection $\left(r^{\mathrm{BA}}\right)$. For C. bransfordii, the top model $\left(w_{m}\right.$ $=0.41$ ) was over one and a half times more likely than other models. For O. pumilio, the top model $\left(w_{m}=0.35\right)$ was rivaled by an equivocally supported model, which included $r^{\mathrm{Ba}}\left(w_{m}=0.33\right)$. Model averaging of parameters strongly supported three parameters for both frogs: $\Psi^{\mathrm{Ba}}$ (C. bransfordii, $\mathrm{w}_{\mathrm{p}}=0.99$; O. pumilio, 
Table 3. Number of parameters $(k), \mathrm{AIC}_{\mathrm{c}}, \Delta \mathrm{AIC}_{\mathrm{c}}$ and model weight $\left(w_{m}\right)$ for the top model set $\left(w_{m}>0.10\right)$ among 60 models built to describe how occupancy and detection patterns of the frogs Craugastor bransfordii and Oophaga pumilio are influenced by predatory ctenid spiders and resources (leaf litter, arthropods) at La Selva, Costa Rica. See Table 1 for explanations of model parameters.

\begin{tabular}{lllll}
\hline Species & Model & $k$ & $\Delta$ AlCc & $w_{m}$ \\
\hline C. bransfordii & $\Psi^{\mathrm{A}} \Psi^{\mathrm{BA}} \Psi^{\mathrm{Ba}} \Psi^{\mathrm{LL}} p^{\mathrm{A}} p^{\mathrm{B}} r^{\mathrm{BA}}$ & 7 & 0.00 & 0.41 \\
\hline & $\Psi^{\mathrm{A}} \Psi^{\mathrm{BA}} \Psi^{\mathrm{Ba}} \Psi^{\mathrm{LL}} p^{\mathrm{A}} p^{\mathrm{B}} r^{\mathrm{BA}} r^{\mathrm{Ba}}$ & 8 & 0.81 & 0.27 \\
\hline & $\Psi^{\mathrm{A}} \Psi^{\mathrm{BA}} \Psi^{\mathrm{Ba}} \Psi^{\mathrm{LL}} p^{\mathrm{A}} p^{\mathrm{B}} r^{\mathrm{BA}} p^{\mathrm{LL}}$ & 8 & 1.70 & 0.18 \\
\hline & $\Psi^{\mathrm{A}} \Psi^{\mathrm{BA}} \Psi^{\mathrm{Ba}} \Psi^{\mathrm{LL}} p^{\mathrm{A}} p^{\mathrm{B}} r^{\mathrm{BA}} r^{\mathrm{Ba}} p^{\mathrm{LL}}$ & 9 & 2.28 & 0.13 \\
\hline 0. pumilio & $\Psi^{\mathrm{A}} \Psi^{\mathrm{BA}} \Psi^{\mathrm{Ba}} \Psi^{\mathrm{LL}} p^{\mathrm{A}} p^{\mathrm{B}} r^{\mathrm{BA}}$ & 7 & 0.00 & 0.35 \\
\hline & $\Psi^{\mathrm{A}} \Psi^{\mathrm{BA}} \Psi^{\mathrm{Ba}} \Psi^{\mathrm{LL}} p^{\mathrm{A}} p^{\mathrm{B}} r^{\mathrm{BA}} r^{\mathrm{Ba}}$ & 8 & 0.13 & 0.33 \\
\hline & $\Psi^{\mathrm{A}} \Psi^{\mathrm{BA}} \Psi^{\mathrm{Ba}} \Psi^{\mathrm{LL}} p^{\mathrm{A}} p^{\mathrm{B}} r^{\mathrm{BA}} p^{\mathrm{LL}}$ & 8 & 1.73 & 0.15 \\
\hline & $\Psi^{\mathrm{A}} \Psi^{\mathrm{BA}} \Psi^{\mathrm{Ba}} \Psi^{\mathrm{LL}} p^{\mathrm{A}} p^{\mathrm{B}} r^{\mathrm{BA}} r^{\mathrm{Ba}} p^{\mathrm{LL}}$ & 9 & 1.79 & 0.14 \\
\hline
\end{tabular}

$\left.\mathrm{w}_{\mathrm{p}}=0.99\right), \Psi^{\mathrm{LL}}\left(\right.$ C. bransfordii, $w_{p}=0.98 ;$ O. pumilio, $\left.\mathrm{w}_{\mathrm{p}}=0.97\right)$ and $r^{\mathrm{BA}}\left(C\right.$. bransfordii, $\mathrm{w}_{\mathrm{p}}=0.99$; O. pumilio, $\mathrm{w}_{\mathrm{p}}=0.99$; Table 4 and 5). While the parameter $r^{\mathrm{Ba}}$ was included in top-model sets for both species, it received low support by model averaging $\left(w_{p}<0.70\right)$ for both frog species.

Model-averaged coefficients described frog occupancy as increasing with leaf-litter mass and, relative to when spiders were present, frog occupancy was elevated when spiders were absent (Figure 2). Occupancy was more strongly predicted by the absence of predators $\left(\Psi^{\mathrm{Ba}}\right)$ than the abundance of leaf litter $\left(\Psi^{\mathrm{LL}}\right)$ or arthropods ( $\left.\Psi^{\text {Arthropods }}\right)$ for both C. bransfordii and O. pumilio (Table 4). These patterns generated SIFs for frogs that described predator avoidance at sites with low leaf litter; however, at sites with increased leaf litter, co-occurrence patterns were independent between frogs and spiders (Figure 3 ). Detection probability of spiders $\left(p^{\mathrm{A}}=0.10-0.12\right)$ was lower than the detection of $C$. bransfordii $\left(p^{\mathrm{B}}=0.29\right)$ and $O$. pumilio $\left(p^{\mathrm{B}}=0.25\right)$, but detection probability of both species increased at sites where spiders were occupants and were detected $\left(r^{\mathrm{BA}}=0.45,0.40\right.$, respectively; Figure 4). Arthropod abundance and seasonality received zero support as effects on frog occupancy and detection (Table 4 and 5).

\section{Discussion}

In our study, site occupancy of both C. bransfordii and O. pumilio in plot cells was more strongly predicted by the presence of spiders than other resources. Specifically, both frogs exhibited decreased occupancy when spiders were present, suggesting that frogs selected habitat to reduce co-occurrence with spider predators. Occupancy of both frogs and spiders was also strongly influenced by leaf-litter abundance at sites, and we observed an effect in which predator avoidance by frogs decreased as litter abundance increased. Variance in frog detection probability was also consistent with predator avoidance: relative to when spiders were absent, detection of $C$. bransfordii and O. pumilio was elevated when spiders were present and detected within plots, suggesting that frogs exhibit more vigilant behaviour when spider predators were present and conspicuous in plots. These results were consistent with the hypothesis that spider predators exert strong ecological effects on prey vertebrates in Central American forests.

Guyer (1988) observed seasonal abundance cycles for populations of a terrestrial anole (Norops humilis) in cacao plantations that oscillated in tandem with the leaf-drop phenology of cacao trees. Because seasonality of leaf litter drives arthropod abundance (Lieberman \& Dock 1982) and N. humilis was experimentally determined to be food limited, Guyer (1988) hypothesised that leaf-fall events at the scale of single canopy trees regulate abundances of terrestrial anoles and similar vertebrates, such as terrestrial frogs. The Guyer (1988) hypothesis assumes that populations are regulated bottom-up by leaf-litter and/or food resources and predicts that (1) anole and frog abundance through primary forest is a mosaic of sites at different stages depending on the leaf-drop phenology of the most proximate tree, and (2) low-resource patches should be vacated seasonally by individuals in search of areas of greater resource quality (hereafter, the litter-mosaic model; Guyer 1988). Our results have implications for reinterpreting and revising the litter-mosaic model in two ways. First, site occupancy of both frogs and N. humilis (Folt 2017) was positively influenced by abundance of leaf litter, but not by the abundance of arthropods used as food. This result suggests that leaf litter alone may drive variance in the litter-mosaic model (i.e., Whitfield et al. 2014). Second, because frog occupancy was more greatly influenced by predators than by litter abundance, predators appear to be an underemphasised control on anuran ecology in a patch-mosaic context. Specifically, our results suggested that frog demography is most sensitive to the presence of predators and only secondarily influenced by the availability of resources, such as leaf litter. In the context of the litter-mosaic model, frogs may still be incentivised to occupy sites of diminished leaf litter or vacate sites with abundant litter, depending on the presence of predators. Thus, our results revise the litter-mosaic model by placing greater emphasis on leaf litter and predators as mechanisms influencing site occupancy of small terrestrial vertebrates in a patchmosaic model.

We observed an interaction between the predators and resources, where predator avoidance by frogs decreased with increasing abundance of leaf litter. The observed interaction between predators and litter suggests that top-down and bottom-up effects on terrestrial frogs do not occur independently in this ecosystem, but rather that habitat characteristics influence species' interactions. Further, the relationship between leaf litter and predator-prey interactions also has implications for understanding seasonal abundance cycles and amphibian declines at La Selva and other comparable wet tropical forests. Because terrestrial leaf-litter abundance is strongly seasonal in lowland Caribbean wet forests like La Selva, our results suggest that food web interactions between spiders and frogs may vary temporally at the seasonal scale (Tunney et al. 2012). Leaf-drop phenology of most trees causes standing leaf litter to reach its greatest depth at the end of the dry season (Frankie et al. 1974, Levings \& Windsor 1984, Folt 2017); as the wet season begins and advances, decreased leaf drop, increased decomposition, and mechanical action of rainfall and shredding action of insects cause standing litter to decrease. While models suggested that predator-prey interactions vary across a gradient of litter abundance, ctenid spiders might exert greater effects on terrestrial frogs during periods of low leaf litter in the wet season. In these situations, decreased occupancy of frogs in the presence of spiders may be driven by reduced refugia in litter, increased risk of predation and/or greater incentive to vacate sites for areas with higher leaf litter. This effect can be extended with implications for models of amphibian population decline at $\mathrm{La}$ Selva, a site that experienced a $75 \%$ decline over a 35 -year period that was hypothesised as a result of climate-driven reductions in the abundance of standing leaf litter (Whitfield et al. 2007). Given observed increase in predator-prey interactions at lower 
Table 4. Model-averaged coefficient values $(\beta)$, unconditional standard error (SE) and parameter weights $\left(w_{p}\right)$ generated by averaging 60 co-occurrence models (Supplementary Table 1) for Craugastor bransfordii and Oophaga pumilio and ctenid spider predators at La Selva, Costa Rica. See Table 1 for explanations of model parameters. Parameter weights were not provided for $\Psi^{\mathrm{A}}$ and $\Psi^{\mathrm{BA}}$ because these parameters were included in all models $\left(w_{p}=1.00\right)$; parameters are not reported for $\Psi^{\text {Arthropods }}$ and $\Psi^{\text {Season }}$ because they received no support.

\begin{tabular}{|c|c|c|c|c|c|c|}
\hline \multirow[b]{3}{*}{ Species } & \multicolumn{6}{|c|}{ Occupancy parameters } \\
\hline & \multirow{2}{*}{$\frac{\text { Intercept }-\Psi^{\mathrm{A}}}{\beta(\mathrm{SE})}$} & \multirow{2}{*}{$\begin{array}{c}\Psi^{\mathrm{BA}} \\
\beta(\mathrm{SE})\end{array}$} & \multicolumn{2}{|c|}{$\Psi^{\mathrm{Ba}}$} & \multicolumn{2}{|c|}{$\Psi \mathrm{LL}$} \\
\hline & & & $\beta$ (SE) & $w$ & $\beta$ (SE) & $w$ \\
\hline O. pumilio & $-2.86(0.78)$ & $-2.29(0.34)$ & $3.41(0.72)$ & 0.99 & $1.03(0.22)$ & 0.97 \\
\hline
\end{tabular}

Table 5. Model-averaged coefficient values $(\beta)$, unconditional standard error (SE) and Akaike parameter weights $\left(w_{\mathrm{p}}\right)$ generated by averaging 60 co-occurrence models (Supplementary Table 1 ) describing patterns of detection for the frogs Craugastor bransfordii and Oophaga pumilio and predatory ctenid spiders at La Selva, Costa Rica. See Table 1 for explanations of model parameters. Parameter weights were not provided for $p^{A}$ and $p^{B}$, because they were included in all models $\left(w_{p}=1.00\right)$; parameters are not reported for $\Psi^{\text {Arthropods }}$ and $\Psi^{\text {Season }}$ because they received no support.

\begin{tabular}{|c|c|c|c|c|c|c|c|c|}
\hline \multirow[b]{2}{*}{ Species } & \multicolumn{8}{|c|}{ Detection parameters } \\
\hline & $\frac{\text { Intercept }-\mathrm{pA}}{\beta(\mathrm{SE})}$ & $\begin{array}{c}\mathrm{pB} \\
\beta(\mathrm{SE})\end{array}$ & $\beta(\mathrm{SE})$ & $w$ & $\beta$ (SE) & $w$ & $\beta$ (SE) & $w$ \\
\hline O. pumilio & $-2.08(0.41)$ & $0.85(0.22)$ & $0.70(0.19)$ & 0.99 & $-0.20(0.09)$ & 0.48 & $0.05(0.10)$ & 0.32 \\
\hline
\end{tabular}

(A)

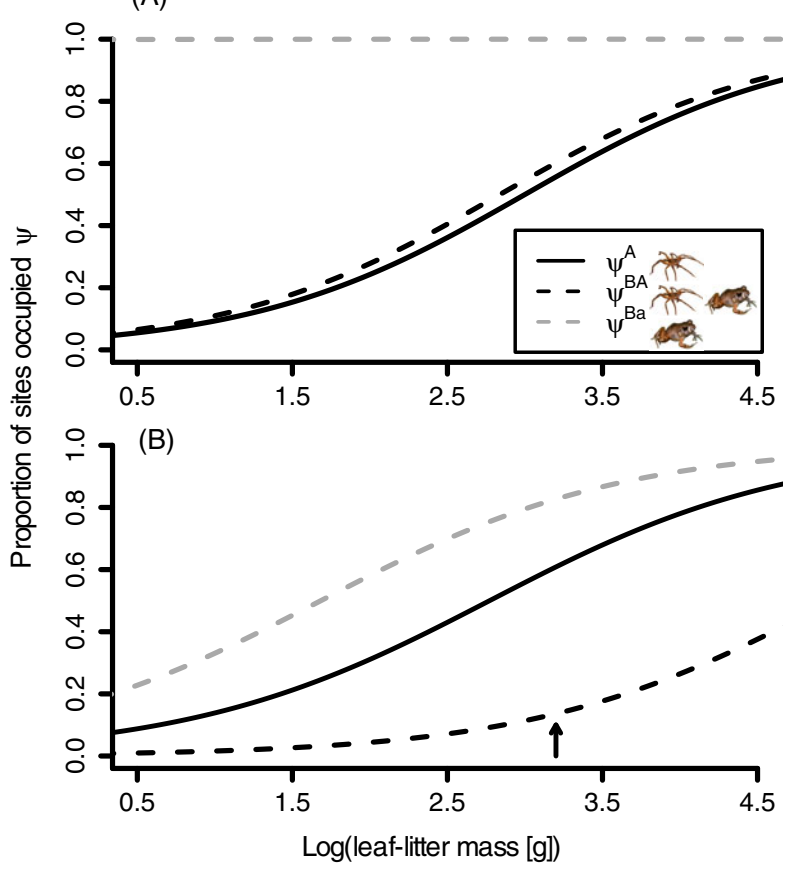

Figure 2. Site occupancy of Craugastor bransfordii (A) and Oophaga pumilio (B) as a function of leaf-litter mass at sites conditionally occupied $\left(\Psi^{\mathrm{BA}}\right)$ and unoccupied $\left(\Psi^{\mathrm{Ba}}\right)$ by predatory spiders (Ctenidae). $\Psi^{\mathrm{A}}$ is the occupancy of spiders. The black arrow indicates the median value of leaf-litter mass for both panels. Results were model-averaged across a balanced design of 60 models (Supplementary Table 1).

levels of litter abundance at La Selva, climate-driven declines in litter could have driven increased predator-prey interactions and a shift in community composition towards decreased abundance of frogs and increased abundance of spider predators. Thus, models of resource-driven amphibian declines (Whitfield et al. 2016) should consider how altered predator-prey relationships may influence community dynamics in these ecosystems.
(A)

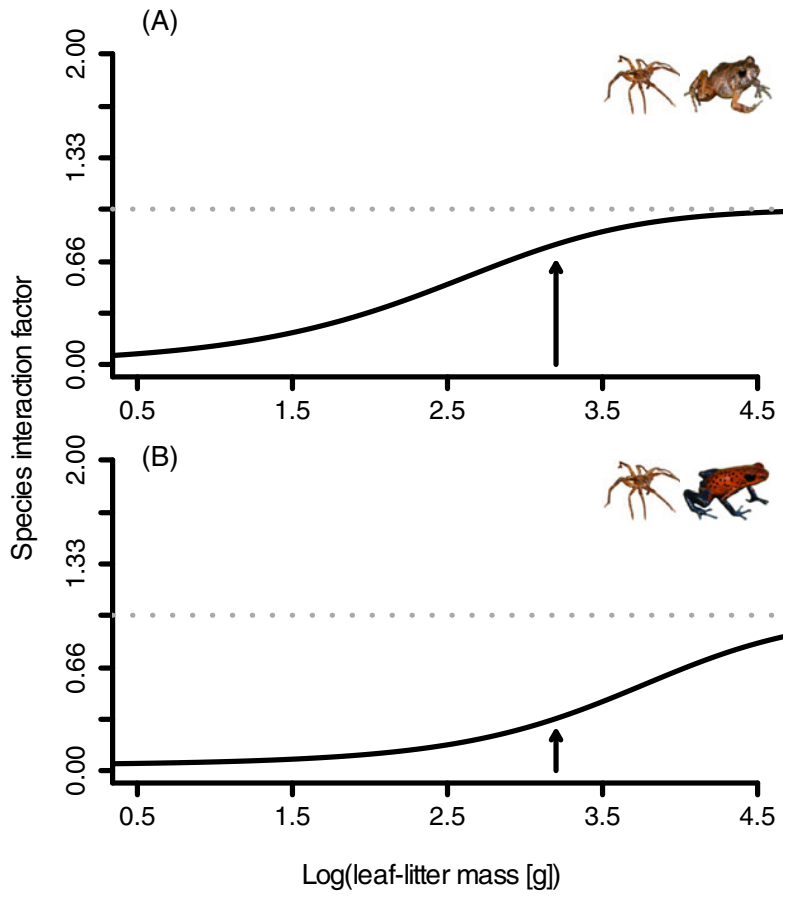

Figure 3. Species interaction factors (SIF) between predatory spiders (Ctenidae) and Craugastor bransfordii (A) and Oophaga pumilio (B) in relation to leaf-litter mass in forest plots at La Selva, Costa Rica. Ctenid spiders are assumed to be dominant over prey frogs. SIF values $<1.0$ indicate avoidance of the subordinate species, values $>1.0$ indicate aggregated with dominate species and values 1.0 (grey dotted line) indicates independent patterns of co-occupancy between spiders and frogs. The black arrows indicates the median value of leaf-litter mass.

Because ctenid spiders are thought to avoid depredating O. pumilio, we predicted that $O$. pumilio would exhibit patterns of occupancy and detection independent of spiders. Contrary to this prediction, occupancy and detection patterns were consistent with spider avoidance and similar to those observed for a species 
(A)

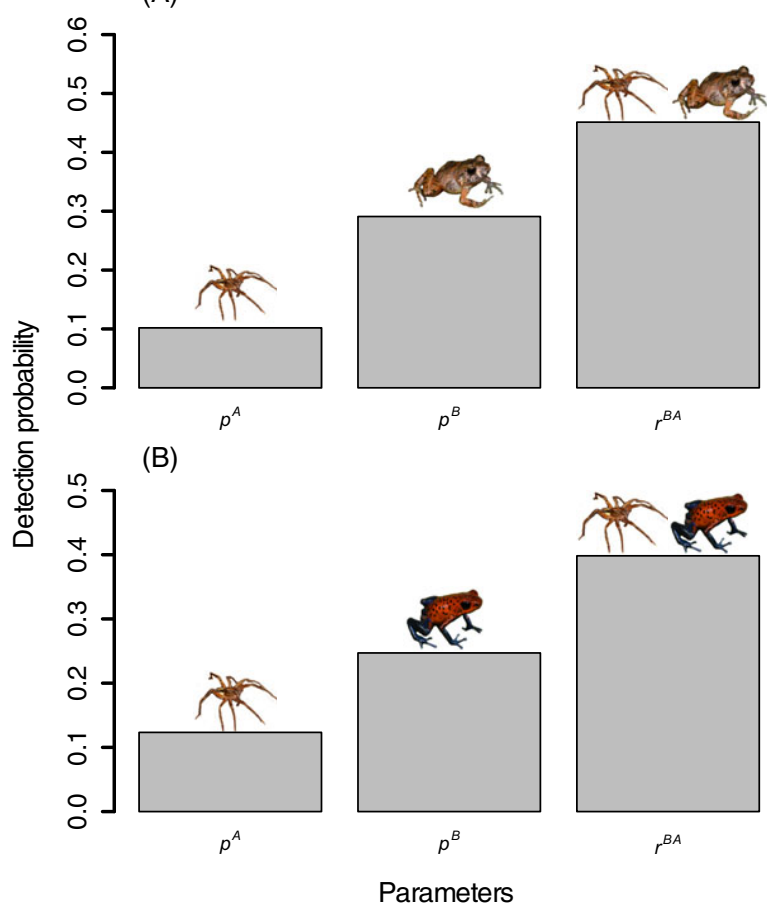

Figure 4. Conditional detection probability of predatory spiders (dominant species; Ctenus sps.) and prey frogs (subordinate species; A - Craugastor bransfordii, B Oophaga pumilio) in terrestrial habitats at La Selva, Costa Rica. $p^{A}$ - detection probability of dominant species, given the subordinate species is absent; $p^{B}$ - detection of the subordinate species, given the dominant species is absent; $r^{\mathrm{BA}}$ - detection of subordinate species, given the dominant species is present and detected.

thought to be frequently consumed by ctenids, C. bransfordii. The spider avoidance effect may be driven by (1) predation attempts by ctenids on $O$. pumilio that occasionally result in frog consumption (e.g., Summers 1999), including at La Selva (M. Chaves, pers. comm.), (2) ctenid predation of $O$. pumilio eggs or tadpoles that have reduced chemical protection than adults (Stynoski et al. 2014a) and/or (3) an innate, general avoidance of spiders by frogs, because anurans in general have shared a long evolutionary history with spider predators. Because O. pumilio responded to spiders in ways consistent with predictions of a predator-prey relationship, our modelling results are at odds with behavioural studies of spider-O. pumilio interactions describing spiders as unimportant predators (Szelistowski 1985, Murray et al. 2016).

In conclusion, our results provide evidence for strong effects of predatory spiders on prey frogs in Central America. Our results supported leaf litter as a bottom-up factor regulating the terrestrial vertebrate assemblage in lowland wet tropical forests but described a stronger and novel top-down effect of predators on anurans that has significant implications for improving models of patch dynamics, seasonal population cycles and amphibian declines (Guyer 1988, Whitfield et al. 2014). While a large literature has suggested or assumed dominant bottom-up regulation of the terrestrial frogs and lizards in this system (Scott 1976, Toft 1980, Guyer 1988, 1994, Fauth et al. 1989, Heinen 1992, Whitfield et al. 2007, 2014, Folt \& Reider 2013), we provided the first evidence supporting a dominant effect of predators regulating this important anuran assemblage, a factor which appears habitat-dependent.

Acknowledgements. Funding support for this project was provided by the Organization for Tropical Studies (Christiane and Christopher Tyson
Fellowship, the Dole Food Fellowship), the National Geographic Society (Young Explorer's Grant), the Society for the Study of Amphibians and Reptiles (Andrew H. Price Field Research Grant), The Herpetologists' League (E.E. Williams Research Grant), Auburn University (Thesis/Dissertation Research Award) and the Auburn University Museum of Natural History (Cunningham Foundation Graduate Research Assistantship). The manuscript benefited from helpful comments from M. Donnelly, S. Hermann, J. Feminella, C. McGowan, J. Hall, A. Tucker and C. McGowan. The study complied with permission from Auburn University IACUC \#2013-1827 and the Costa Rican government (MINAET Resolución \#009-2014). This paper is contribution no. 948 of the Auburn University Museum of Natural History.

Supplementary material. To view supplementary material for this article, please visit https://doi.org/10.1017/S0266467421000274

\section{References}

Andrews RM (1979) Evolution of life histories: A comparison of Anolis lizards from matched islands and mainland habitat. Breviora 454, 1-51.

Burnham KP and Anderson DR (2010) Model Selection and Multimodel Inference: A Practical Information-theoretic Approach (Second). New York: Springer-Verlag.

Cooper WE, Caldwell JP and Vitt LJ (2008a) Escape responses of cryptic frogs (Anura: Brachycephalidae: Craugastor). Behaviour 145, 25-38.

Cooper WE, Caldwell JP and Vitt LJ (2008b) Effective crypsis and its maintenance by immobility in Craugastor frogs. Copeia 2008, 527-532.

Donnelly MA (1989) Demographic effects of reproductive resource supplementation in a territorial frog, Dendrobates pumilio. Ecological Monographs 59, 207-221.

Donnelly MA (1991) Feeding patterns of the strawberry poison frog, Dendrobates pumilio (Anura: Dendrobatidae). Copeia 3, 723-730.

Donnelly MA and Guyer C (1994) Patterns of reproduction and habitat use in an assemblage of Neotropical hylid frogs. Oecologia 98, 291-302.

Fauth JE, Crother BI and Slowinski JB (1989) Elevational patterns of species richness, evenness, and abundance of the Costa Rican leaf-litter herpetofauna. Biotropica 21, 178-185.

Folt B (2017) Population regulation of frogs and lizards in a lowland wet Neotropical forest: integrating alternative hypotheses. Auburn University. $166 \mathrm{pp}$.

Folt B and Lapinski W (2017) New observations of frog and lizard predation by wandering and orb-weaver spiders in Costa Rica. Phyllomedusa 16, 269-277.

Folt B and Reider KE (2013) Leaf-litter herpetofaunal richness, abundance, and community assembly in mono-dominant plantations and primary forest of northeastern Costa Rica. Biodiversity and Conservation 22, 2057-2070.

Frankie GW, Baker HG and Opler PA (1974) Comparative phenological studies of trees in tropical wet and dry forests in the lowlands of Costa Rica. Journal of Ecology 62, 881-919.

Greene HW (1988) Species richness in tropical predators. In Almeda F and Pringle CM (eds), Tropical Rainforests: Diversity and Conservation. San Francisco, CA: California Academy of Sciences and Pacific Division, American Association for the Advancement of Science, pp. 259-280.

Guyer C (1988) Food supplementation in a tropical mainland anole, Norops humilis: demographic effects. Ecology 69, 350-361.

Guyer C and Donnelly MA (2005) Patterns of co-occurrence of hylid frogs at a temporary wetland in Costa Rica. In Donnelly MA, Crother BI, Guyer C, Wake MH and White ME (eds), Ecology and Evolution in the Tropics: A Herpetological Perspective. Chicago, IL: University of Chicago Press, pp. 227-242.

Guyer C (1994) The Reptile Fauna: Diversity and Ecology. In McDade LA, Bawa KS, Hespenheide H and Hartshorn GS (eds), La Selva: Ecology and Natural History of a Neotropical Rain Forest. Chicago, IL: University of Chicago Press, pp. 210-216.

Hayes MP (1983) Predation on the adults and prehatching stages of glass frogs (Centrolenidae). Biotropica 15, 74-76.

Heinen JT (1992) Comparisons of the leaf litter herpetofauna in abandoned cacao plantations and primary rain forest in Costa Rica. Biotropica 24, 431-439. 
Hunter MD and Price PW (1992) Playing chutes and ladders: heterogeneity and the relative roles of bottom-up and top-down forces in natural communities. Ecology 73, 724-732.

Hurvich CM and Tsai C-L (1989) Regression and time series model selection in small samples. Biometrika 76, 297-307.

Lapinski W and Tschapka M (2013) Habitat use and coexistence in an assemblage of Neotropical wandering spiders. Journal of Arachnology 41, 151-159.

Levings SC and Windsor DM (1984) Litter moisture content as a determinant of litter arthropod distribution and abundance during the dry season on Barro Colorado Island, Panama. Biotropica 16, 125-131.

Lieberman SS (1986) Ecology of the leaf litter herpetofauna of a Neotropical rain forest: La Selva, Costa Rica. Acta Zoologica Mexicana 15, 1-72.

Lieberman SS and Dock CF (1982) Analysis of the leaf litter arthropod fauna of a lowland tropical evergreen forest site (La Selva, Costa Rica). Revista de Biología Tropical 30, 27-34.

Losos JB (2009) Lizards in an Evolutionary Tree: Ecology and Adapative Radiation of Anoles. Berkeley, CA: University of California Press.

Mackenzie DI, Bailey LL and Nichols JD (2004) Investigating species cooccurrence patterns when species are detected imperfectly. Journal of Animal Ecology 73, 546-555.

Mackenzie DI and Hines JE (2016) RPresence: R Interface for Program PRESENCE.

Mackenzie DI, Nichols JD, Royle JA, Pollock KH, Bailey LL and Hines JE (2006) Occupancy Estimation and Modeling: Inferring Patterns and Dynamics of Species Occurrence. Burlington, Masschusetts, USA: Elsevier.

Maffei F, Ubaid FK and Jim J (2010) Predation of herps by spiders (Araneae) in the Brazilian Cerrado. Herpetology Notes 3, 167-170.

Mcdade LA, Bawa KS, Hespenheide H and Hartshorn GS (1994) La Selva: Ecology and Natural History of a Neotropical Rain Forest. Chicago, IL: University of Chicago Press.

Mendelson JR, Lips KR, Gagliardlo RW, Rabb GB, Collins JP, Diffendorfer JE, Daszak P, Roberto Ibáñz D, Zippel KC, Lawson DP, Wright KM, Stuart SN, Gascon C, da Silva HR, Burrowes PA, Joglar RL, La Marca E, Lötters S, du Preez LH, Weldon C, Hyatt A, Rodriguez-Mahecha JV, Hunt S, Robertson H, Lock B, Raxworthy CJ, Frost DR, Lacy RC, Alford RA, Campbell JA, Parra-Olea G, Bolaños F, Domingo JJC, Halliday T, Murphy JB, Wake MH, Coloma LA, Kuzmin SL, Price MS, Howell KM, Lau M, Pethiyagoda R, Boone M, Lannoo MJ, Blaustein AR, Dobson A, Griffiths RA, Crump ML, Wake DB and Brodie ED (2006) Confronting amphibian declines and extinctions. Science 313, 48.

Meneses AS de O, Corrêa BAAP, Fernades MDR, Lopes BEPDC, Citeli NK and Brandão RA (2021) What size of Neotropical frogs do spiders prey on? Biologia 76, 919-932.

Menin M, de Jesus Rodrigues D and Salette de Azevedo C (2005) Predation on amphibians by spiders (Arachnida, Araneae) in the Neotropical region. Phyllomedusa 4, 39-47.

Murray EM, Bolton SK, Berg T and Saporito RA (2016) Arthropod predation in a dendrobatid poison frog: Does frog life stage matter? Zoology 119, 169174. Elsevier GmbH.

Nyffeler M and Altig R (2020) Spiders as frog-eaters: A global perspective. Journal of Arachnology 48, 26-42.

R Core Team (2018) R: A language and environment for statistical computing. Vienna, Austria: R Foundation for Statistical Computing.

Reyes-Olivares C, Guajardo-Santibáñez A, Segura B, Zañartu N, Penna M and Labra A (2020) Lizard predation by spiders: A review from the Neotropical and Andean regions. Ecology and Evolution 10, 10953-10964.

Richmond OMW, Hines JE and Beissinger SR (2010) Two-species occupancy models: a new parameterization applied to co-occurrence of secretive rails. Journal of Applied Ecology 20, 2036-2046.

Saporito RA, Donnelly MA, Norton RA, Garraffo HM, Spande TF and Daly JW (2007a) Oribatid mites as a major dietary source for alkaloids in poison frogs. Proceedings of the National Academy of Sciences of the United States of America 104, 8885-8890.

Saporito RA, Garraffo HM, Donnelly MA, Edwards AL, Longino JT and Daly JW (2004) Formicine ants: An arthropod source for the pumiliotoxin alkaloids of dendrobatid poison frogs. Proceedings of the National Academy of Sciences of the United States of America 101, 8045-8050.
Saporito RA, Zuercher R, Roberts M, Kenneth G and Donnelly MA (2007b) Experimental evidence for aposematism in the dendrobatid poison frog Oophaga pumilio. Copeia 2007, 1006-1011.

Savage JM and Emerson SB (1970) Polymorphism allied to Eleutherodactylus bransfordii (Cope): A problem of polymorphism. Copeia 1970, 623-644.

Scheele BC, Pasmans F, Skerrat LF, Berger L, Martel A, Beukema W, Acevedo AA, Burrowes PA, Carvalho T, Catenazzi A, de la Riva I, Fisher MC, Flechas SV, Foster CN, Frías-Álvarez P, Garner TWJ, Gratwicke B, Guayasamin JM, Hirschfield M, Kolby J, Kosch TA, La Marca E, Lindenmayer DB, Lips KR, Longo AV, Maneyra R, Mcdonald CA, Mendelson JRI, Palacios-Rodriguez P, Parra-Olea G, RichardsZawacki CL, Rödel M, Rovito SM, Soto-Azat C, Felipe Toledo L, Voyles J, Weldon C, whitfield SM, Wilkinson M, Zamudio KR and Canessa S (2020) Amphibian fungal panzootic causes catastrophic and ongoing loss of biodiversity. Science 1463, 1459-1463.

Schlaepfer MA (2003) Successful lizard eggs in a human-disturbed habitat. Oecologia 137, 304-311.

Scott NJJ (1976) The abundance and diversity of the herpetofaunas of tropical forest litter. Biotropica 8, 41-58.

Seebacher F and Alford RA (2002) Shelter microhabitats determine body temperature and dehydration rates of a terrestrial amphibian (Bufo marinus). Journal of Herpetology 36, 69-75.

Sih A (1984) The behavioral response race between predator and prey. The American Naturalist 123, 143-150.

Socci AM, Schlaepfer MA and Gavin TA (2005) The importance of soil moisture and leaf cover in a female lizard's (Norops polylepis) evaluation of potential oviposition sites. Herpetologica 61, 233-240.

Stuart SN, Chanson JS, Cox NA, Young BE, Rodrigues AS, Fischman DL and Waller RW (2004) Status and trends of amphibian declines and extinctions worldwide. Science 306, 1783-1786.

Stynoski JL, Shelton G and Stynoski P (2014a) Maternally derived chemical defences are an effective deterrent against some predators of poison frog tadpoles (Oophaga pumilio). Biology Letters 10, 20140187.

Stynoski JL, Torres-Mendoza Y, Sasa-Marin M and Saporito RA (2014b) Evidence of maternal provisioning of alkaloid-based chemical defenses in the strawberry poison frog Oophaga pumilio. Ecology 95, 587-593.

Summers K (1999) Dendrobates auratus (Green Poison Frog). Predation. Herpetological Review 30, 91.

Szelistowski WA (1985) Unpalatability of the poison arrow frog Dendrobates pumilio to the ctenid spider Cupiennius coccineus. Biotropica 17, 345-346.

Talbot JJ (1979) Time budget, niche overlap, inter- and intraspecific aggression in Anolis humilis and A. limifrons from Costa Rica. Copeia 1979, 472-481.

Toft CA (1980) Seasonal variation in populations of Panamanian litter frogs and their prey: A comparison of wetter and drier sites. Oecologia 47, 34-38.

Tunney TD, Mccann KS, Lester NP and Shuter BJ (2012) Food web expansion and contraction in response to changing environmental conditions. Nature Communications 3, 1105-1109. Nature Publishing Group.

von May R, Biggi E, Cárdenas H, Isabel Diaz M, Alarcón C, Herrera V, SantaCruz R, Tomasinelli F, Westeen EP, Sánchez-Paredes CM, Larson JG, Title PO, Grundler MR, Grundler MC, Davis Rabosky AR and Rabosky DL (2019) Ecological interactions between arthropods and small vertebrates in a lowland Amazon rain forest. Amphibian and Reptile Conservation 13(1), 65-77.

Whitfield S, Bell KE, Philippi T, Sasa M, Bolaños F, Chaves G, Savage JM and Donnelly MA (2007) Amphibian and reptile declines over 35 years at La Selva, Costa Rica. Proceedings of the National Academy of Sciences of the United States of America 104, 8352-8356.

Whitfield SM and Donnelly MA (2006) Ontogenetic and seasonal variation in the diets of a Costa Rican leaf-litter herpetofauna. Journal of Tropical Ecology 22, 409-417.

Whitfield SM, Lips KR and Donnelly MA (2016) Amphibian decline and conservation in Central America. Copeia 2016, 351-379.

Whitfield SM, Reider K, Greenspan S and Donnelly MA (2014) Litter dynamics regulate population densities in a declining terrestrial herpetofauna. Copeia 14, 454-461. 